\title{
Social Interactions of TB Patients at Helvetia Community Health Center in Medan
}

\author{
Elis Anggeria ${ }^{1}$, Yosni Yohana Sipayung ${ }^{1}$, Kristin Mei Sara Zebua $^{1}$ \\ ${ }^{1}$ Faculty of Nursing and Midwifery, Universitas Prima Indonesia, Medan, Indonesia
}

\begin{abstract}
Social interaction is a relationship between humans, both in individuals and in groups. Social interaction in society occurs because of social contact and communication. Pulmonary TB is an infectious disease caused by Mycobacterium tuberculosis. This study aimed to determine the social interaction of pulmonary tuberculosis patients at Helvetia Community Health Center in Medan. This study used a descriptive design. The population in this study were all patients suffering from pulmonary tuberculosis. The sample size was determined using a purposive sampling technique, and it was found that the sample size was 33 respondents. The data collection used observation form. The data analysis used frequency distribution. The result shows various respondents' characteristics. The majority were 29-43 years old, male, high school educated, self-employed, and have suffered from $\mathrm{TB} \leq 3$ years. Based on the study result, 25 of 33 sample patients with pulmonary tuberculosis still interacted socially with their community. The conclusion is that patients with pulmonary tuberculosis still socially interact with the community in their neighborhood.
\end{abstract}

Keyword: interaction; social; pulmonary TB

Received 12 $2^{\text {th }}$ March 2021 | Revised 17 $7^{\text {th }}$ May $2021 \mid$ Accepted $8^{\text {th }}$ June 2021

*Corresponding author: J1 Danau Singkarak, Gg. Madrasah, Sei Agul, Kec. Medan Barat, Medan, Indonesia

E-mail address: elisanggeria@unprimdn.ac.id 


\section{Introduction}

Mycobacterium Tuberculosis causes pulmonary tuberculosis disease that attacks the human lungs. Mycobacteria tuberculosis also attacks other organs of the body. Pulmonary tuberculosis transmits through coughing, saliva, drinking water, and food. Everyone can suffer from Pulmonary tuberculosis. However, it was found that people at a young age or productive age, 15-50 years old, predominantly suffer from this disease, significantly weakened people, malnourished, and living in the same house with pulmonary tuberculosis sufferers (World Health Organization [WHO], 2017).

According to the World Health Organization (WHO) data, pulmonary tuberculosis has become a worldwide problem disease. Several disease control efforts have been made, and the death rate due to the disease has decreased. In 2014, it was estimated that pulmonary tuberculosis affected 9.6 million people, resulting in around 1.2 million deaths. Countries with the most pulmonary tuberculosis sufferers are India, Indonesia, and China, with a respective percentage of $23 \%$, $10 \%$, and $10 \%$ of all sufferers in the world (WHO, 2015). One of its transmission is through tiny droplets, and TB patients with TBA+ emit these tiny droplets. If this disease is not treated completely, it can lead to dangerous complications, even death (Kementerian Kesehatan RI, 2014).

There was an increase in Indonesia's tuberculosis cases in 2015 compared to 2014. In 2015, there were 330,910 tuberculosis cases, while there were 324,539 tuberculosis cases in 2014. Due to their large populations, West Java, Central Java, and East Java provinces become the provinces with the most pulmonary tuberculosis cases all over Indonesia (Kementerian Kesehatan RI, 2016). In North Sumatra, there was a difference in pulmonary tuberculosis cases in 2016 and 2017. The 2016 profile data of the North Sumatra Health Department stated that there were 17,798 new pulmonary tuberculosis cases. According to the Health Profile of North Sumatra Regency/City in 2017, the success rate of TB treatment (Success Rate/SR) reached $91.31 \%$ at the provincial level. There was a slight decrease compared to the $92.19 \%$ achievement in 2016 . The TB cure percentage was $82.40 \%$ in 2017 , a slight decrease compared to the 2016 achievement, $85.52 \%$.

In their research, Pribadi, Karyanto, and Yansuri (2019) at Negeri Lampung Indonesia showed that $75.0 \%$ of pulmonary tuberculosis patients interacted poorly, and $25 \%$ interacted well. According to Saraswati, Nur, and Basirun (2016), the pre-survey result conducted at $R S P K U$ Muhammdiyah Gombong showed that $70 \%$ of patients less socially interacted due to changes in their body. They became skinny, and they were uncomfortable interacting with others. Meanwhile, $30 \%$ of patients kept interacting with their surroundings. 
According to Damsar (2015), Social Interaction is direct contact or communication between two people or more. There are two types of social interaction. Associative and Dissociative. Then, there are three types of associative social interaction-cooperation for mutual needs; accommodation for resolving problems through compromise, coercion, tolerance, and conciliation; assimilation by respecting each other differences and acceptance (Nasdian, 2015). Based on Sutrisno's (2014) research result at RSUD Kusta Donorojo Jepara, 63.6\% of patients with infectious diseases had sufficient social interaction, and $36.4 \%$ had good self-identities.

Based on the observation results or preliminary survey results, it was found that patients with pulmonary tuberculosis had difficulties undergoing the treatment process. This was due to unfavorable public assumptions about the disease. Thus, the researcher wanted to deeply examine the social interactions within the Helvetia Community Health Center in Medan. This research is substantial to provide proper information about social interaction for pulmonary tuberculosis patients visiting Helvetia Community Health Center in Medan to improve their health.

\section{Research Methods}

This research used a descriptive method to identify the social interaction portrayal of Pulmonary Tuberculosis patients at Helvetia Community Health Center in Medan. The population in this study includes all pulmonary tuberculosis patients totaling 50 cases. This study also used purposive sampling as its sampling technique to acquire 33 respondents as samples to be studied.

The primary data were obtained through questionnaires filled out by every pulmonary tuberculosis patient at Helvetia Community Health Center in Medan. Before filling out the questionnaire, each of them was asked about their willingness to become a respondent. If they are willing to participate, they must sign a letter of consent. After that, a brief description of the questionnaire will be given to them. If the respondents are uncomfortable with the questions, they are allowed to stop filling out the questionnaire. If they are comfortable with the questions, they can continue to fill them out till the end. The secondary data were obtained from pulmonary tuberculosis patient's medical records. Also, this study used the ethical clearance granted by the University. The measurement aspect was carried out using a questionnaire containing social interaction on pulmonary tuberculosis patients. The researcher developed the questionnaires for this study. The data analysis used Univariate data by displaying the frequency distribution data. 


\section{Research Result}

The research results of characteristics of respondents are as follows:

Table 1. Characteristics of Respondents

\begin{tabular}{|c|c|c|c|}
\hline No. & Characteristics of Respondents & Frequency (f) & Percentage (\%) \\
\hline \multirow[t]{6}{*}{1} & Age & & \\
\hline & 14-28 years & 7 & 21.2 \\
\hline & $29-43$ years & 12 & 36.4 \\
\hline & $44-58$ years & 10 & 30.3 \\
\hline & $59-73$ years & 4 & 12.1 \\
\hline & Total & 33 & 100 \\
\hline \multirow[t]{4}{*}{2} & Gender & & \multirow{3}{*}{$\begin{array}{l}63.6 \\
36.4\end{array}$} \\
\hline & Men & 21 & \\
\hline & Women & 12 & \\
\hline & Total & 33 & 100 \\
\hline \multirow[t]{6}{*}{3} & Education & & \\
\hline & Elementary School & 3 & 9,1 \\
\hline & Junior High School & 5 & 15.2 \\
\hline & Senior High school & 20 & 60.6 \\
\hline & College & 5 & 15.2 \\
\hline & Total & 33 & 100 \\
\hline \multirow[t]{6}{*}{4} & Profession & & \\
\hline & Civil servants & 0 & 0 \\
\hline & Self-employed & 20 & 60.6 \\
\hline & Farmer & 2 & 6.1 \\
\hline & Others & 11 & 33.3 \\
\hline & Total & 33 & 100 \\
\hline \multirow[t]{4}{*}{5} & Years of Suffering & & \\
\hline & $\leq 3$ years & 26 & 78.8 \\
\hline & $\geq 3$ years & 7 & 21.2 \\
\hline & Total & 33 & 100 \\
\hline
\end{tabular}

Based on Table 1 above, most respondents were aged between 29-43 years old (36.4\%), while the minority were aged between 59-73 years old (12.1\%). Based on gender, most respondents were men $(63.6 \%)$, while women were $36.4 \%$. Based on the education level, most respondents were high school graduates $(60.6 \%)$, while the minority were elementary school graduates (9.1\%). Based on occupation, most respondents were self-employed $(60.6 \%)$, while the minority were farmers $(6.1 \%)$. Based on years of suffering, most respondents were $\geq 3$ years long of suffering $(78.8 \%)$, while the minority was $\leq 3$ years $(21.2 \%)$. 
The research results of social interaction are as follows:

Table 2. Social Interaction of Pulmonary TB Patients at Helvetia Community Health Center in Medan

\begin{tabular}{clcc}
\hline No. & Social interaction & Frequency $(\mathbf{f})$ & Percentage $\mathbf{( \% )}$ \\
\hline 1 & Good & 25 & 75.8 \\
2 & Enough & 5 & 15.2 \\
3 & Less & 3 & 9,1 \\
\hline & Total & $\mathbf{3 3}$ & $\mathbf{1 0 0}$ \\
\hline
\end{tabular}

Based on Table 2 above, from the 33 respondents, $75.8 \%$ have good social interaction, $15.2 \%$ have enough social interaction, and $9.1 \%$ have less social interaction.

\section{Research Discussion}

The results obtained show that the respondents have a good social interaction. This shows that the respondent understands well about pulmonary tuberculosis after being explained by the health team. Respondents also used health facilities to treat pulmonary tuberculosis, participated in a monitoring program for ingesting TB drugs, and underwent treatment recommended by the government. The health workers explained in detail to the respondent how to take pulmonary TB medicine. When the research was taking place, respondents did not shy away from researchers or the community. Respondents wore masks and kept their distance when talking to other people. Respondents communicate with family members as usual and are accepted in their neighborhood. Respondents were facilitated by their families in the healing process, slept separately, and implemented procedures to prevent the spread of pulmonary tuberculosis both inside and outside the house. The family also reminded the respondent of the schedule to take medication regularly.

This study shows that the most characteristic of respondents is male. Many male patients suffer from pulmonary tuberculosis because they tend to have many activities, including outside activities. The research result also showed that most of them are self-employed workers. In his research, Sarmen (2016) stated that self-employed workers mostly have respectable interactions with others. They perform direct contact with their colleagues and their neighborhood where they live. Muslim (2013) stated that social interaction is a relationship between humans, either individually, in groups, or socially.

The research also found that the respondents performed adequate social interaction with others. The reason is that the respondents did not entirely comprehend pulmonary tuberculosis. Not many respondents used health facilities such as BPJS and KIS (Kartu Indonesia Sehat). Still, they wear masks and keep their distance when talking to other people. In addition, only a few of 
them is following community activities after suffering from pulmonary tuberculosis. Regarding the education for treatment of pulmonary tuberculosis, health workers have explained how to take medicine in detail. The respondents underwent medication as recommended by the government, and the family facilitated their healing process. Also, their neighborhood favorably accepted the respondents, while some of the respondents avoid meeting the community. Research by Tristina, Richa, and Makhfudli (2019) found that respondents still maintain social interactions with other people.

In terms of education, most respondents have senior high school education. A high level of education becomes a factor in developing one's knowledge while performing social interaction. Sarmen's research (2017) stated that respondent's high level of education affects their knowledge and understanding of diseases. Because of that they can interact as usual within their social environment. Meanwhile, the minority respondents of this study have elementary school education. Low-level education is also a factor affecting the lack of comprehension of one's knowledge towards relationships and social interactions. Research by Yuliana, Fathra, and Riri (2013) stated that respondents with low-level education have difficulties receiving information about pulmonary tuberculosis they suffer.

This study also found some less-social interaction respondents. It shows that respondents had their low-level education, making them struggle to perceive any information about the disease. Some respondents did not use health facilities when treating pulmonary tuberculosis. They underwent complete self-isolation and did not interact with others. Some of them were never invited by their family to attend community activities and reluctant to meet the community due to a stigma towards pulmonary tuberculosis sufferers.

Regarding social interaction, Laksono's research (2017) shows that social interaction cannot be avoided, especially in social life. Human needs other people to get information and ask for help. Mocodompis's research (2015) stated that social interaction is a series of activities conducted between one, two, or more people having a communication occurring at a certain time to achieve a common goal. As a result, respondents performing good social interaction can communicate, seek, and receive information from health facilities properly.

\section{Conclusion}

Pulmonary tuberculosis sufferers are still interacting socially in their neighborhoods. They do this to acquire information about pulmonary tuberculosis treatment and care. They are also wearing masks and keeping their distance when interacting with others. 


\section{REFERENCES}

[1] Damsar. (2015). Pengantar Teori Sosiologi. Jakarta: Prenada Media Grup.

[2] Dinas Kesehatan Provinsi Sumatera Utara. (2016). Profil Kesehatan Provinsi Sumatera Utara Tahun 2015.

[3] Kementerian Kesehatan Republik Indonesia Direktorat Jenderal Pengendalian Penyakit dan Penyehatan Lingkungan.(2014). Petunjuk Teknis Manajemen Terpadu Pengendalian Tuberkulosis ResistanObat. Jakarta: Kemenkes RI.

[4] Kementerian Kesehatan Republik Indonesia. Peraturan Menteri Kesehatan Republik Indonesia No.67 Tahun 2016 Tentang Penanggulangan Tuberculosis. Kemenkes RI: 2016.

[5] Laksono, R, N. (2017). The influence of social interaction on work motivation in Maulana Malik Ibrahim State Islamic University Students of Malang Who Work Part Time.

[6] Mocodompis, R, J. (2015). Patterns of community social interaction in supporting village government implementation. Accessed via, media.neliti.com.publications.

[7] Muslim, A. (2013). Social interaction in a multiethnic society. Journal of Islamic Discourse Volume 1 Number 3. https://doi.org/10.5539/ass.v12n7p47.

[8] Nasdian, F.T. (2015). Sosiologi umum. Jakarta: Yayasan Pustaka Obor Indonesia.

[9] Pribadi, T., Karyanto., \& Yansuri. (2019). The relationship between self-image in social interaction in patients with pulmonary tuberculosis in Negeri Agung Lampung, Indonesia. Holistic Health Journal, Volume 13.

[10] Saraswati, R., Nur, H., M, \& Basirun, A, U. (2016). Self-concept of pulmonary tuberculosis patients at PKU Muhammadiyah Gombong Hospital. Nursing Health Scientific Journal, Volume 12

[11] Sarmen, DR, Surya, H. FD., \& Suyanto. (2017). Description of knowledge and attitudes of pulmonary tuberculosis patients towards TB control efforts at Sidomulyo Health Center, Pekan Baru City. Jom FK Vol. 4.

[12] Sutrisno, F, I. (2014). The relationship between the dimensions of self-concept and social interaction among people with leprosy at the Leprosy Hospital Donorojo, Jepara. http://digilib.unimus.ac.id/files//disk1/141/jtptunimus-gdl-findiisaks-7030-19.

[13] Tristina, D, RR., Richa, K., \& Makhfudli. (2019). The experience of clients of pulmonary tuberculosis who underwent intensive phase treatment at the Magetan District Health Center. Vol. 4, No. February 1, 2019. http://dx.doi.org/10.20473/ijchn.v4i1.12353.

[14] Yuliana., Fathra, A, N., \& Riri, N. (2013). The relationship between self-esteem and behavior in patients with pulmonary tuberculosis (TB).

[15] World Health Organization. (2017). Global Tuberculosis Report. Geneva: WHO Press; 2017. 